and D. George (eds.)

\title{
A new species of the genus Aonides Claparède, 1864 (Polychaeta: Spionidae) from the Macaronesian region (Eastern Central Atlantic)
}

\author{
MARÍA DEL CARMEN BRITO, JORGE NÚÑEZ and RODRIGO RIERA \\ Laboratorio de Bentos, Departamento de Biología Animal (Zoología), Facultad de Biología, Universidad de La Laguna, \\ 38206 La Laguna, Tenerife, Canary Islands, Spain. E-mail: janunez@ull.es
}

\begin{abstract}
SUMMARY: A new spionid of the genus Aonides Claparède, 1864 has been collected in a muddy sand bottom of a marine cave from the Selvagens Islands. This genus included seven species, two of which have been recorded from the central Macaronesian region: Aonides oxycephala (Sars 1862) and the new species Aonides selvagensis. The new species differs from the remaining Aonides species by the presence of 5 anal cirri, 6-8 pairs of branchiae, the absence of eyes, and shape and arrangement of the parapodial hooks.
\end{abstract}

Keywords: Polychaeta, Spionidae, Aonides, Atlantic, Macaronesia, Selvagens Islands, Canary Islands.

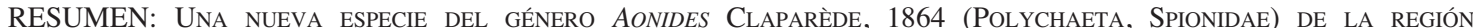
MACARONÉSiCA (ATLÁNTICo CENTRAL DEL ESTE). - Un nuevo espiónido del género Aonides Claparède, 1864 ha sido colectado en un fondo de arena fangosa en una cueva submarina de las Islas Salvajes. Este género agrupa a siete especies, dos de las cuales han sido registradas en la región de la Macaronesia central: Aonides oxycephala (Sars 1862) y la nueva especie A. selvagensis. Esta especie se diferencia de las otras especies de Aonides por la presencia de 5 cirros anales, 6-8 pares de branquias, la ausencia de ojos, y por la forma y distribución de los ganchos parapodiales.

Palabras clave: Polychaeta, Spionidae, Aonides, Atlantico, Macaronesia, Selvagens Islands, Islas Canarias.

\section{INTRODUCTION}

The Spionidae is one of the families with the greatest number of species in midlittoral and shallow subtidal habitats worldwide, with over 1,000 species belonging to 33 genera (Sigvaldadóttir et al., 1997). In the Canary Islands (central Macaronesian region), the first records of Spionidae were by Langerhans (1881), Núñez et al. (1984), and Maciolek $(1985,2000)$. Recent works on endobiont polychaetes from demosponges (Pascual, 1996) and fauna associated with Cymodocea nodosa rhizomes (Brito-Castro, 1999), increased the number of species of the Spionidae from the central Macaronesia to 19 species.

The genus Aonides Claparède, 1864 includes six species with a worldwide distribution (Blake et al., 1996): A. oxycephala (Sars, 1862), A. paucibranchiata Southern, 1914, A. californiensis Rioja, 1947, A. trifida Estcourt, 1967, A. mayaguezensis Foster, 1971, and A. glandulosa Blake, 1996. Until now, only one species has been recorded from the study area, A. oxycephala (Bellán, 1969). 


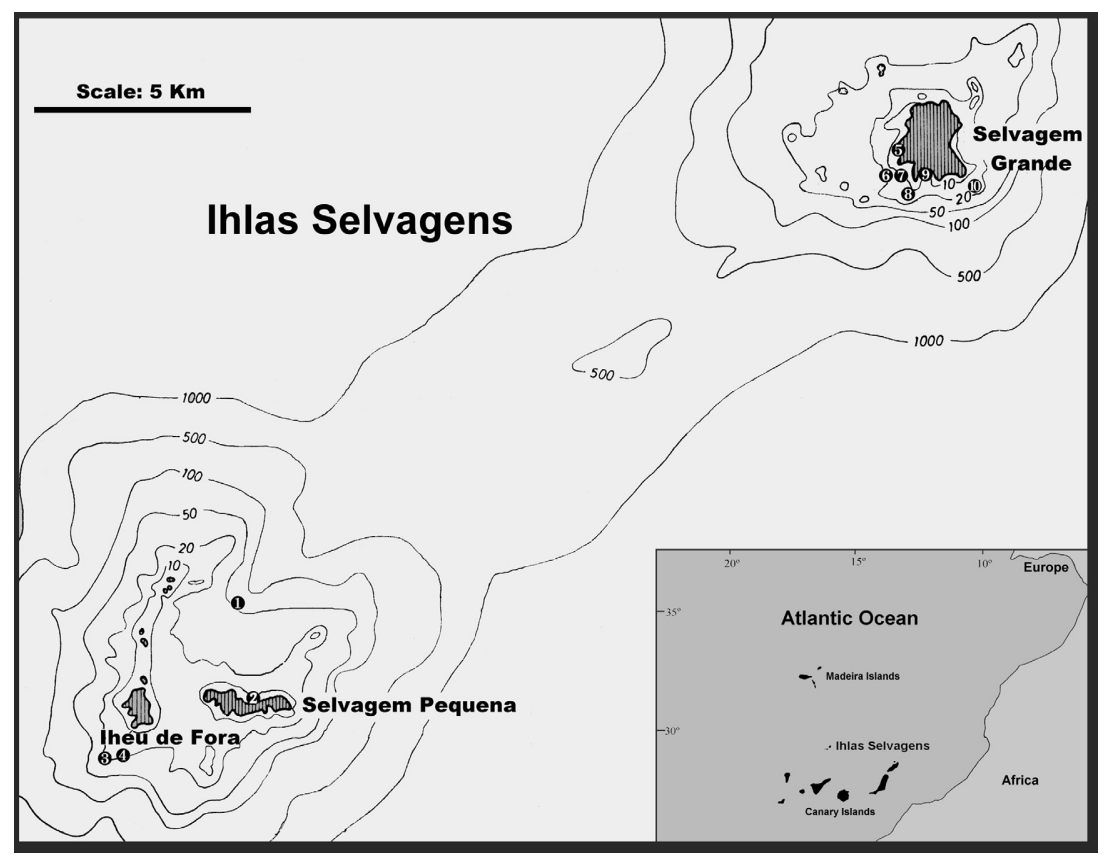

FIG. 1. - Map of Selvagens Islands, showing sampling stations (circles 1-10) and the location of the Macaronesian Central region (Madeira, Selvagens and Canary Islands).

\section{MATERIAL AND METHODS}

The samples were taken during 1994 from Ensenada de los Abades (SE of Tenerife, Canary Islands) in a sandy bottom of Cymodocea nodosa seagrass, and in a muddy sand bottom from Selvagens Islands (Fig. 1), during the "Macaronesia 2000" expedition in May 1999 on board the R.V. "Corvette".

Samples were collected by scuba-diving at depths of 13-18 $\mathrm{m}$ and drilling into the sediment with PVC tubes. The tubes employed were $45 \mathrm{~cm}$ long with a $4.5 \mathrm{~cm}$ inner diameter. The samples were preserved in buffered $10 \%$ seawater/ formaldehyde and sieved through a $100 \mu \mathrm{m}$ mesh. Sorted specimens were preserved in $70 \%$ alcohol. Several specimens were mounted in glycerine gel and drawings were made using a camera lucida on a Leica DMLB microscope equipped with Nomarski interference contrast. Some specimens were examined with scanning electron microscopy (SEM, Jeol JSM-6300), after critical point drying and gold sputtering.

The specimens were deposited at the Museo de Ciencias Naturales de Madrid (MCNC), Museo de Ciencias Naturales de la Naturaleza y el Hombre de Tenerife (TFMC) and at the Departamento de Biología Animal (Zoología), Universidad de La Laguna (DBAULL).

\section{SYSTEMATICS}

Aonides Claparède, 1864

Diagnosis. Prostomium conical, narrow, and tapered anteriorly; occipital tentacle and eyes present or absent. Peristomium fused to the prostomium, without lateral wings. Branchiae beginning on chaetiger 2 , present in the anterior region of the body; branchiae all cirriform, not fused to the dorsal lamellae. Chaetae of two types: limbate capillaries anteriorly, and bidentate, tridentate or tetradentate hooded hooks arranged in the notopodia and neuropodia of the median and posterior region. Pygidium with 2-12 acuminate anal cirri.

Type species: Nerine oxycephala Sars, 1862

\section{Aonides oxycephala (Sars, 1862)}

Nerine oxycephala Sars, 1862: 64.

Aonides auricularis Claparède, 1864: 505, lam. 3, fig. 3.

Aonides oxycephala Fauvel, 1927: 39, fig. 13 a-e; Day, 1967: 478, fig. 18.6 d-g; Ramos, 1976: 11, fig. 1-2; Imajima, 1989: 215, fig. 2.

Material examined. Canary Islands, Tenerife, Ensenada de los Abades, coordinates UTM: 358200/3112600, 2 specimens in sandy bottom without vegetation at $13 \mathrm{~m}$ depth and 1 specimen in Cymodocea nodosa meadows at $14 \mathrm{~m}$ depth, September 1994, col. J. Núñez.

Remarks. The three specimens from Tenerife are of small size, 12-15 mm long, with 12-13 branchial 
pairs, and with the typical bidentate hooded hooks on noto- and neuropodia. Specimens agree well with the descriptions of Aonides oxycephala by Ramos (1976) and Imajima (1989).

Ecology. The species was collected in only two of 96 samples from Cymodocea nodosa seagrass beds. The sediment was composed of fine sand $\left(\mathrm{Q}_{50}=0.224\right)$ with moderately sorted sand $\left(\mathrm{S}_{0}=1.66\right)$, and with low organic matter $(0.48 \%)$, carbonates $(7.5 \%)$ and nitrogen content $(0.032 \%)$. It is a common species in mud, sand, gravel and mixed sediments with shell remains and high organic matter content (Parapar 1991), although Viéitez (1978) also recorded it in fine sand poor in organic matter.
Distribution: Atlantic-Mediterranean region, from Mozambique to Madagascar, Australia and Japan, California. Possibly circumtropical.

\section{Aonides selvagensis n. sp.}

(Figs. 2-3)

Aonides sp. Núñez et al., 2001: 39.

Type locality: Selvagens Islands, Grand Selvagem, Baia das Cagarras, station 7 (see Fig. 1) coordinates UTM: 416250/3334458, 15 m depth, in a muddy sand bottom of a marine cave, May 1999, col. J. Núñez.

Type material. Holotype, whole-mounted in glycerine gel, TFMCBMAN/000218. Paratypes: 3 specimens in 70\% alcohol, DBAULL PO-51999; 6 whole-mounted specimens in glycerine gel (1 spec. TFMCBMAN/000219; 5 spec. DBAULL PO-AS51999).

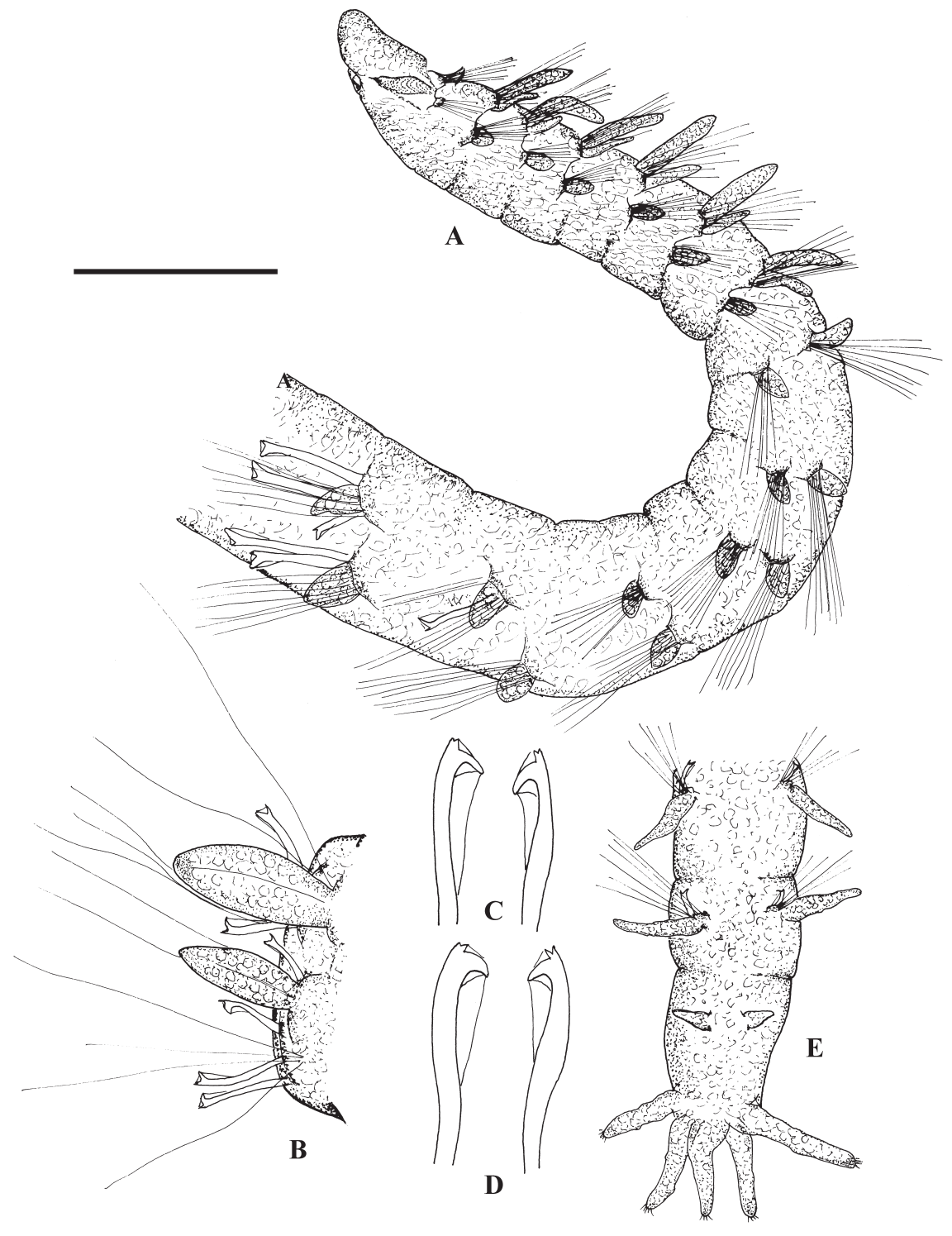

FIG. 2. - A, anterior end, lateral view; B, parapodium 38, posterior view; C, notopodial hooded hooks, parapodium 13; D, neuropodial hooded hooks, parapodium 13; E, posterior end, dorsal view. Scale bar: A $=0.25 \mathrm{~mm} ; \mathrm{B}=62 \mu \mathrm{m} ; \mathrm{C}, \mathrm{D}=25 \mu \mathrm{m} ; \mathrm{E}=31 \mu \mathrm{m}$. 

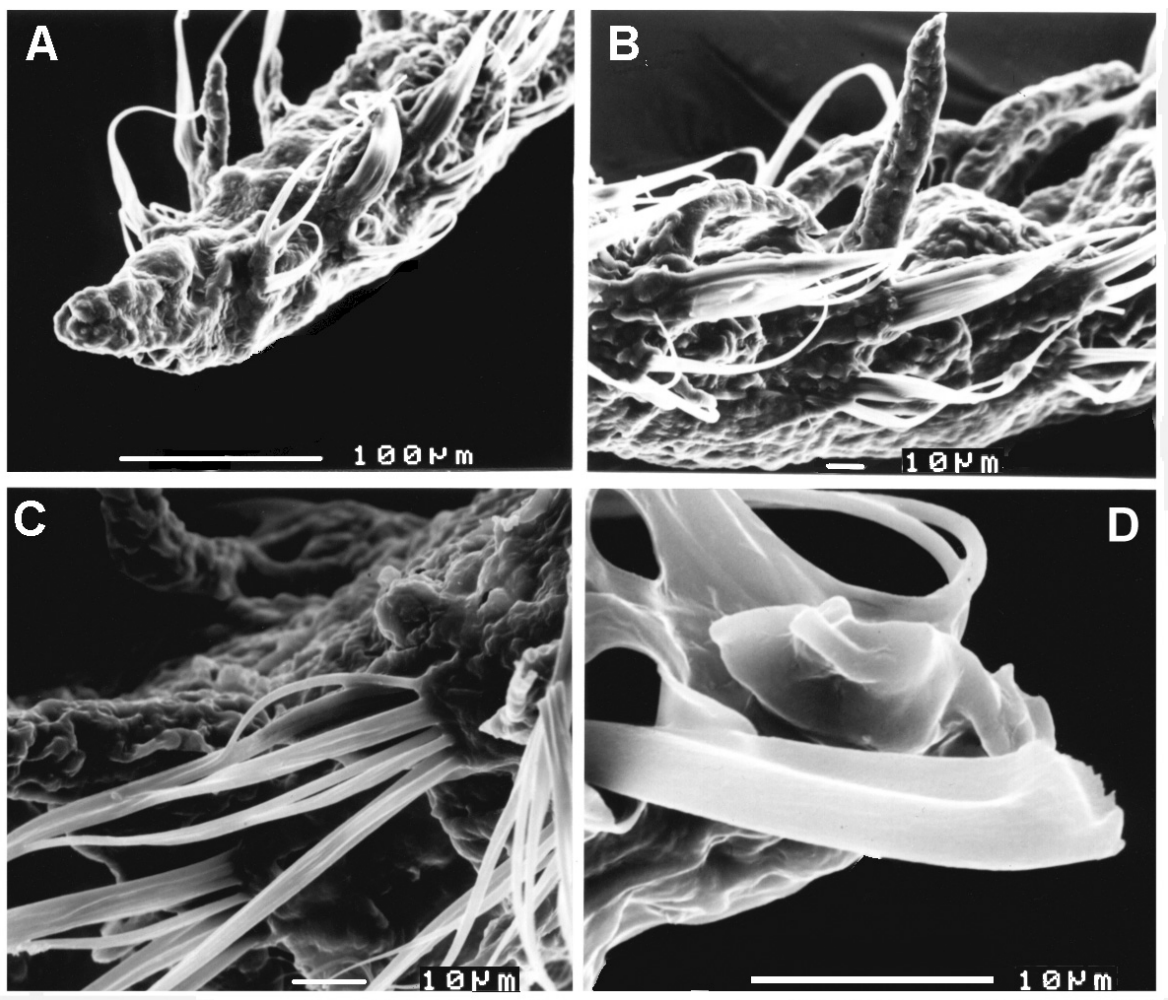

FIG. 3. - A, anterior end, dorso-lateral view; B, branchial region, dorsal view; C, capillary chaetae; D, hooded hook chaeta, bifid secondary tooth. (SEM photographs).

Additional material. Canary Islands, Tenerife, Cueva de los Cerebros, coordinates UTM: 322550/3117655, 10 spec., DBAULL PO-AS82003, $7 \mathrm{~m}$ depth, fine sand and muddy sand bottoms, August 2003, col. J. Núñez and Ó. Monterroso.

Description. Largest preserved specimen 9.25 $\mathrm{mm}$ long and $0.23 \mathrm{~mm}$ wide on chaetiger 3 , with 52 chaetigers (holotype). Body more or less rounded in cross section, dorsally flattened in the branchial region. Prostomium conical, anteriorly pointed (Fig. 2A, 3A), widest about two-thirds back and tapered posteriorly to about level of chaetiger 1 , with a caruncle poorly develop (Fig. 3A). Lacking eyes, occipital antenna, and lateral wings. Peristomium surrounding the posterior half of the prostomium. Palps lost in all specimens. Chaetiger 1 with small notopodial and neuropodial postchaetal lamella. Branchiae cirriform and ciliated, present from chaetiger 2, 6-8 pairs (Fig. 2A, 3A, B). All branchiae separate from notopodial lamellae, each about as long as body width. The seventh branchial pair sometimes rudimentary or even absent. (Fig. 2A, B). Chaetigers of branchial region with small cirriform postchaetal notopodial lamella and rounded postchaetal neuropodial lamella. Chaetigers of abranchial region with conical lamellae, postchaetal lamella slightly larger. The last chaetigers with prechaetal lamella cirriform.
Chaetae all smooth capillaries in branchial region (Fig. 3B), arranged in two rows (Fig. 3C), numbering 11-12 in notopodial fascicles and 8-9 in neuropodial fascicles, decreasing number towards the postbranchial region. Chaetigers 1-12 with 10 simple chaetae, chaetigers 13-30 with 5-7, and chaetigers 30-52 with 2-4. Tridentate hooded hooks with a main fang and two equal teeth (Fig. 2C, D, 3D); neuropodial hooded hooks 1-5 per fascicle from chaetiger 11; notopodial hooks 1-4 per fascicle from chaetiger 13 (Fig. 2A, B). Prepygidial segment without chaetae and hooded hooks (holotype). Pygidium with 5 ciliated anal cirri (Fig. 2E).

Etymology. The specific name selvagensis refers to the type locality (Selvagens Islands), where the species was collected for the first time.

Remarks. The new species Aonides selvagensis is characterized by the presence of tridentate hooded hooks, 6-8 pairs of branchiae, absence of eyes, and five anal cirri. Aonides selvagensis most closely resembles A. paucibranchiata Southern, 1914 in having tridentate hooded hooks and a similar number of branchial pairs. A. selvagensis differs in the absence of eyes, the first occurrence of the notopo- 
TABLE 1. - Taxonomic characters of Aonides species.

\begin{tabular}{|c|c|c|c|c|c|c|}
\hline & $\mathrm{N}^{\mathrm{o}}$ of eyes & $\begin{array}{l}\mathrm{N}^{o} \text { branchial } \\
\text { pairs }\end{array}$ & $\begin{array}{l}\text { Notopodial hooks } \\
\text { from chaetiger } n^{\circ}\end{array}$ & $\begin{array}{l}\text { Neuropodial hooks } \\
\text { from chaetiger } n^{\circ}\end{array}$ & $\begin{array}{l}\text { Hooded } \\
\text { hooks }\end{array}$ & $\begin{array}{l}\mathrm{N}^{\mathrm{o}} \text { of anal } \\
\text { cirri }\end{array}$ \\
\hline A. oxycephala (Sars, 1862) & 4 & $10-30$ & $30-46$ & $28-46$ & Bidentate & $2-12$ \\
\hline A. paucibranchiata Southern, 1914 & 4 & $6-11$ & $22-36$ & $17-31$ & Tridentate & 4 \\
\hline A. californiensis Rioja, 1947 & 4 & $13-14$ & 35 & 40 & Bidentate & 4 \\
\hline A. trifida Estcourt, 1967 & 4 & $12-18$ & $30-406$ & $30-34$ & Tetradentate & 6 \\
\hline A. mayaguezensis Foster, 1971 & 4 & $15-16$ & $20-38$ & $19-23$ & Bidentate & 4 \\
\hline A. glandulosa Blake, 1996 & $0-4$ & $8-11$ & $34-41$ & $30-39$ & Bidentate & 4 \\
\hline A. selvagensis $\mathrm{n} . \mathrm{sp}$. & 0 & $6-8$ & 13 & 11 & Tridentate & 5 \\
\hline
\end{tabular}

dial hooded hooks (chaetigers 22-36 in A. paucibranchiata and chaetiger 13 in A. selvagensis) and neuropodial hooks (chaetigers 17-30 in A. paucibranchiata and chaetiger 11 in A. selvagensis). The pygidium has four anal cirri in A. paucibranchiata and five cirri in A. selvagensis (see Table 1).

Distribution. Central Macaronesian region (Selvagens and Canary Islands) (Fig. 1).

\section{DISCUSSION}

Morphological studies concerning the variability of taxonomic characters in species of Aonides, have shown that the approaches to distinguishing the species of the genus are inadequate (Ramos, 1976). Ramos observed a great variability in populations of A. oxycephala, reaching the conclusion that A. californiensis and A.mayaguezensis are junior synonym of A. oxycephala. A comparative revision of the type material is needed to elucidate the validity of the species (see Table 1). Within the seven known species of the genus two groups can be distinguished based on the type of hooded hooks that are present. The first group, characterized by having bidentated hooks, contains the species: A. californiensis, A. mayaguezensis, A. oxycephala and A. glandulosa. The second group with tri- and tetradentated hooded hooks contains: A. paucibranchiata, A. trifida and the new species A. selvagensis. The apomorphic character of tetradentated hooks (three divisions in the distal tooth- Estcourt, 1967) in A. trifida, distinguishes this species from the others in the second group. A. paucibranchiata and A. selvagensis n. sp. are closely related, both having tridentate hooks. $A$. paucibranchiata is an amphiatlantic species with some records from the Atlantic-Mediterranean region and is possibly present in the Canaries sand- banks, since the polychaete fauna is similar throughout the region. Aonides selvagensis n. sp. possesses some adaptations for life in marine caves and other interstitial environments with low light intensity, e.g. small size, below $10 \mathrm{~mm}$ long, and lacks eyes while the other species are larger (10-20 mm long); and have eyes.

\section{AKNOWLEDGEMENTS}

This paper was partially supported by the project "Macaronesia 2000" of the Museum of Natural Sciences of Santa Cruz de Tenerife. Special thanks to Dr. J.J. Bacallado director of the project and to the crew of R.V. "Corvette". The comments and suggestions of two anonymous referees greatly improved the manuscript.

\section{REFERENCES}

Bellán, G. - 1969. Annélides polychaètes recuillies dans l'Archipiel de Madére au cours de la champagne scientifique dunávrie océanographique «Jean Charcot» (Juillet 1966). Cah. Biol. Mar., 10: 35-57.

Blake, A.J., B. Hilbig and P.H. Scott. - 1996. Taxonomic Atlas of the Benthic Fauna of the Santa María Basin and Western Santa Barbara Channel. Sant. Bar. Mus. Nat. Hist., 6(3): 100-103.

Brito-Castro, M.C. - 1999. Estudio de las comunidades intersticiales del sebadal (Cymodocea nodosa) en Canarias con especial referencia a los Anélidos Poliquetos. PhD thesis, Univ. of La Laguna.

Claparède,E. - 1864. Glanures zootomiques parmi les annélides de Port-Vendres (Pyrénées Orientales). Mém. Soc. Phys. Hist. Nat. Gen., 17(2): 463-600, pls. 1-8.

Day, J.H. - 1967. A monograph on the Polychaeta of Southern Africa. Part I: Errantia. Trustees Brit. Mus. (Nat. Hist.). London.

Estcourt, I.N. - 1967. Burrowing Polychaete worms from a New Zealand Estuary. Trans. Roy. Soc. N. Z., 9(7): 63-78.

Fauvel, P. - 1927. Faune de France. 16: Polychétes Sedentaires. Le Chevalier ed., Paris.

Imajima, M. - 1989. Spionidae (Annelida, Polychaeta) from Japan I. The Genera Aonides and Apoprionospio. Bull. Nat. Sci.Mus., 15(4): 213-222.

Langerhans, P. - 1881. Ueber einige canarische Anneliden. Nov. Act. Leop., 42: 93-124.

Maciolek, N.J. - 1985. A revision of the genus Prionospio 
64 • M.C. BRITO et al.

Malmgrem, with special emphasis on species from the Atlantic Ocean, and new records of species belonging to the genera Apoprionospio Foster and Paraprionospio Caullery (Annelida, Polychaeta, Spionidae). Zool. J. Linn. Soc., 84: 325-383.

Maciolek, N.J. - 2000. New species and records of Aonidella, Laonice, and Spiophanes (Polychaeta: Spionidae) from shelf and slope depths of the western north Atlantic. Bull.Mar. Sci., 67(1): 529-574.

Núñez, J., M.C. Brito and J.J. Bacallado - 1984 Catálogo provisional de los anélidos poliquetos del archipiélago canario. Actas del III Simp. Ibérico de Estudios del Bentos Marino. Cuad. Marisq. Publ. Téc., 7: 113-148.

Núñez, J., R. Riera, M.C. Brito and M. Pascual. - 2001. Anélidos Poliquetos intersticiales de las Islas Salvajes. Vieraea, 29: 29-46.

Parapar, J. - 1991. Anélidos Poliquetos bentónicos de la Ría de Ferrol (Galicia). Tesis Doctoral. Univ. de Santiago de Compostela.
Pascual, M. - 1996. Poliquetos endobiontes de esponjas de Tenerife y Madeira. Tesis de Licenciatura. Univ. de La Laguna.

Ramos, J.M. - 1976. Aonides oxycephala (Sars, 1862) Remarques taxoinomiques. Vie Milieu, 26 (1A)XXVI, fasc. 1, sér. A: 1120.

Sars, M. - 1862. Om Annelidslegten Nerine og dans norske Arten. Forh. Vidensk. Selsk. Krist., (18): 59-67.

Sigvaldadóttir, E., A.S.Y. Mackie and F. Pleijel. - 1997. Generic interrelationships within the Spionidae (Annelida: Polychaeta). Zool. J. Linn. Soc., 119: 473-500.

Viéitez, J.M. - 1978. Comparación ecológica de dos playas de las rías de Pontevedra y Vigo. Tesis Doctoral, Univ. Complutense, Madrid.

Received September 15, 2004. Accepted July 4, 2005. 